\title{
Anastrozole induced irreversible hepatotoxicity: Frailty and adverse drug reactions
}

\author{
Rawan Khuwaileh*, Timothy Green and Subramaniam Nagasayi \\ Senior Clinical Fellow, Foundation year 2, Consultant Geriatric Medicine, UK
}

\begin{abstract}
The selective aromatase inhibitor anastrozole is used as adjuvant treatment in early and advanced estrogen receptor positive breast cancer in postmenopausal women. Hepatotoxicity secondary to anastrozole is uncommon but usually reversible. We report irreversible and fatal liver failure in our patient with non-metastatic breast carcinoma who was commenced on it four months prior to admission. She had no risk factors for chronic liver disease. She scored as moderately frail on Rockwood Clinical frailty scale (CFS 6) and unfortunately succumbed as the liver failure worsened despite drug withdrawal.
\end{abstract}

\section{Case report}

A seventy-two-year-old woman underwent right mastectomy with axillary nodes dissection for localized infiltrative lobular breast carcinoma in July 2017. She also required a total abdominal hysterectomy with bilateral salpingo-oophorectomy (TAH/BSO) for endometrial carcinoma in February 2015.

Baseline liver function tests (LFT) in September 2018 prior to commencement of anastrozole $1 \mathrm{mg}$ per day, were normal. In December 2018 , i.e. three months after starting treatment, the patient developed jaundice and then was admitted with delirium. (CFS 6, moderately frail)

Laboratory tests showed severe cholestasis: alanine transaminase $33 \mathrm{U} / \mathrm{l}$, alkaline Phosphatase $614 \mathrm{U} / \mathrm{l}$, bilirubin $317 \mu \mathrm{mol} / \mathrm{L}$, gamma glutamyl transferase $468 \mathrm{U} / \mathrm{l}$, ammonia $90 \mu \mathrm{mol} / \mathrm{L}$ (normal value: $<50$ ). CT scan of abdomen confirmed no evidence of hepatic metastases or extra and intrahepatic biliary ductal dilatation. Anastrozole was then discontinued. During the admission, serum alkaline phosphatase and bilirubin continued to worsen despite normal transaminases.

Patient's usual medications included furosemide $20 \mathrm{mg}$, mirtazapine $15 \mathrm{mg}$, laxido, morphine sulphate $10 \mathrm{mg}$ and alendronic acid $70 \mathrm{mg}$. She did not consume any alcohol and a thorough review by pharmacists revealed no other offending drugs. A gastroenterology consultation was undertaken however a liver biopsy was not considered due to frailty and worsening general condition. Viral hepatitis and autoimmune screen were not performed in view of normal transaminases throughout the illness. Unfortunately, no clinical or biochemical improvement was observed, and she succumbed to liver failure which lead to death 3 weeks after drug withdrawal.

\section{Discussion}

The BNF lists hepatotoxicity of Anastrozole as an uncommon adverse reaction i.e. a frequency of 1 in 1000 . The mechanism is variable (Table 1) [1-8] and almost all the reported cases had reversible effect with prompt clinical and laboratory improvement. However liver failure worsened in our patient despite its withdrawal.
Table 1. Anastrozole hepatotoxicity reported in the literature

\begin{tabular}{|c|c|c|}
\hline Study & $\begin{array}{c}\text { Mechanism of Anastrozole induced } \\
\text { Hepatotoxicity Reversibility }\end{array}$ & Age of Patient \\
\hline Inno et al. [1] & Autoimmune Hepatitis & Reversible $70 \mathrm{y}$ \\
\hline Klapko et al. [2] & Autoimmune Hepatitis & Reversible $71 \mathrm{y}$ \\
\hline Islam et al. [3] & Autoimmune Hepatitis & Reversible $66 \mathrm{y}$ \\
\hline Lacey and Evans [4] & Steatohepatitis & Reversible $48 \mathrm{y}$ \\
\hline Cruz et al. $[5]$ & $\begin{array}{c}\text { Diffuse liver cell necrosis and mixed } \\
\text { steatohepatitis and cholestasis }\end{array}$ & Reversible $58 \mathrm{y}$ \\
\hline Lin et al. [6] & Steatohepatitis & Not mentioned $60 \mathrm{y}$ \\
\hline Zapta et al. [8] & Mixed cholestasis and hepatitis & Reversible $89 \mathrm{y}$ \\
\hline
\end{tabular}

Anastrozole is extensively metabolized in the liver by $\mathrm{N}$-dealkylation, hydroxylation and glucuronidation, therefore, a genetic polymorphism of any enzyme involved in drug detoxification could cause an accumulation of the parental drug or its metabolites, predisposing to liver toxicity [1]. However, no data exist on the cytochromes involved in Anastrozole hepatic detoxification. Pharmacological studies suggest that the risk of cytochrome P (CYP) mediated drug-drug interactions is negligible in individuals treated with Anastrozole, the study indicated that although it can inhibit CYP1A2, 2C9, and 3A-mediated catalytic activities, clinically significant interactions with other CYP-metabolized drugs is not expected [7].

In the United Kingdom, rates of drug related hospital admissions vary widely (from $0.1 \%$ to $45 \%)$. Wu (2010) examined data for all English hospital admissions using the Hospital Episode Statistics Database in the time period 1999 to 2008. Between 1999 and 2008, there were 557,978 adverse drug reactions associated admissions,

${ }^{\star}$ Correspondence to: Rawan Khuwaileh, Department of Geriatrics, Senior Clinical Fellow, Foundation year 2, UK, Tel: 00447774295642, E-mail: rawan_khuwaileh@yahoo.com

Key words: Anastrozole, breast cancer, hepatotoxicity, irreversible, Rockwood frailty scale

Received: December 01, 2019; Accepted: December 09, 2019; Published: December 13,2019 
which represented $0.9 \%$ of total hospital admissions in the time period mentioned. Over this period the annual number of adverse drug reactions increased by $76.8 \%$ and in-hospital mortality rate increased by $10 \%$. In 2008 , there were $6,830,067$ emergency admissions of which 75,076 were due to adverse drug reactions [9].

The learning point is to consider medications in the differential diagnosis of any older person admitted with an unexplained organ involvement [10]. Older persons with frailty are more vulnerable to and also lesser able to recover from adverse drug reactions [11].

Written informed consent for publication of their clinical details was obtained from the proxy.

\section{References}

1. Inno A, Basso M, Vecchio FM, Marsico VA, Cerchiaro E, et al. (2011) Anastrozolerelated acute hepatitis with autoimmune features: a case report. BMC Gastroenterol 11: 32. [Crossref]

2. Klapko O, Ghoulam E, Jakate S, Eswaran S, Usha L (2017) Anastrozole-induced Autoimmune Hepatitis: A Rare Complication of Breast Cancer Therapy. Anticancer Res 37: 4173-4176. [Crossref]
3. Islam MS, Wright G, Tanner P, Lucas R (2014) A case of anastrazole-related druginduced autoimmune hepatitis. Clin J Gastroenterol 7: 414-417. [Crossref]

4. Lacey R, Evans A (2014) An unusual cause of jaundice in a patient with breast cancer BMJ Case Rep pii: bcr2014205764. [Crossref]

5. De la Cruz L, Romero-Vazquez J, Jiménez-Sáenz M, Padron JRA, Herrerias-Gutierrez JM (2007) Severe acute hepatitis in a patient treated with anastrozole. Lancet 369 : 23-24. [Crossref]

6. Lin Y, Liu J, Zhang X, Li L, Hu R, et al. (2014) A prospective, randomized study on hepatotoxicity of anastrozole compared with tamoxifen in women with breast cancer. Cancer Sci 105: 1182-1188. [Crossref]

7. Grimm SW and Dyroff MC (1997) Inhibition of human drug metabolizing cytochromes P450 by anastrozole, a potent and selective inhibitor of aromatase. Drug Metab Dispos 25: 598-602. [Crossref]

8. Zapata E, Zubiaurre L, Bujanda L, Piérola A (2006) Anastrozole-induced hepatotoxicity. Eur J Gastroenterol Hepatol 18: 1233-1234. [Crossref]

9. Wu TY, Jen MH, Bottle A, Molokhia M, Aylin P, et al. (2010) Ten-year trends in hospital admissions for adverse drug reactions in England 1999-2009. J R Soc Med 103: 239-250. [Crossref]

10. Ferner RE and McGettigan P (2018) Adverse drug reactions. BMJ 363: k4051.

11. Hilmer (2017) Prescribing for frail older people. Aust Prescr 40: 174-178. [Crossref]

Copyright: $@ 2019$ Khuwaileh R. This is an open-access article distributed under the terms of the Creative Commons Attribution License, which permits unrestricted use, distribution, and reproduction in any medium, provided the original author and source are credited. 